\title{
Characteristics of multi-annual variation of precipitation in areas particularly exposed to extreme phenomena. Part 1. The upper Vistula river basin
}

\author{
Bernard Twaróg ${ }^{1, *}$ \\ ${ }^{1}$ Faculty of Environmental Engineering, Cracow University of Technology, Warszawska Str. 24, \\ 31-155 Cracow, Poland
}

\begin{abstract}
The study contains an analysis of precipitation, covering multiple profiles and based on the GPCC database that provides monthly mean values for the territory upper Vistula catchment. The analysis includes data for the period 1901-2010 with a spatial resolution of $0.5^{\circ} \times 0.5^{\circ}$ of geographic longitude and latitude. The initial section of the analysis contains an assessment of GPCC data accuracy for the territory of Poland and the period 1961-1990. The following sections include a data analysis in monthly profiles and hydrological cycle profiles, taking into account hydrological summer and hydrological winter. A cluster analysis is also included, with drought and flood periods indicated. The periodical nature of precipitation is assessed and the trends in climate changes calculated.
\end{abstract}

\section{Introduction}

The demand for temporal and spatial characteristics of atmospheric precipitation, despite numerous studies published and analyses completed [1-8], has grown in recent decades due to the documented hypotheses proposing effects of human activities on regional climate factors. New computational capacities and comprehensive analyses covering long measurement series also attract the interest of researchers who test out their hypotheses proposing escalation and polarization of extreme phenomena. The renewed interest in climate factors, including atmospheric precipitation, also results from accumulation of flood damages and periods of hydrological drought.

The available studies of variations in atmospheric precipitation demonstrate changes in statistical trends, depending on the period observed, and provide a basis for an assessment of the nature and directions of those changes. The results of assessments of the pluvial nature of precipitation, demonstrating a reduction in the proportion of total summer precipitation, also indicate a reduced continental influence [3]. The trend analyses [5, 8] demonstrate an increased variability of precipitation.

\footnotetext{
${ }^{1}$ Corresponding author: btwarog@pk.edu.pl
} 


\section{Water resources assesment for purpose of regional planning}

There is a growing body of scientific evidence confirming the hypothesis proposing climate changes caused by human activities. The intensity of those changes depends on the region and varies in time and space. The analyses of climate changes at a regional level demonstrate a strong correlation with anthropogenic impacts. The climate changes observed are characterised by shortened period of high-intensity precipitation and more frequent periods of long-lasting precipitation that cause great floods. Also the periods characterised by high temperatures and reduced precipitation have become longer. The polarization of extreme phenomena is an established fact, associated with the variations in and intensity of human activities.

The Polish National Water Management Strategy for 2030 emphasises that water retention is insufficient already at present. An effective plan for flood control capacity is necessary to balance the consequences of an increase in the volumes of flowing bodies of water. On the other hand, retention of usable and manageable water resources is required to overcome the consequences of droughts. The total volume of flowing water in Poland amounts to 61.9 billion $\mathrm{m}^{3} /$ year on average, including $88 \%$ of domestic resources. The total natural capacity of Polish lakes amounts to about 18.2 billion $\mathrm{m}^{3}$, plus additional 3.5 billion $\mathrm{m}^{3}$ or more in retention reservoirs. The relatively small total capacity of Polish retention reservoirs, estimated to be about 4 billion $\mathrm{m}^{3}$ and representing less than $6 \%$ of the long-term mean annual outflow, is insufficient to ensure the full protection against floods and droughts, a safe level of water supplies to the consumer population and to the industrial and agricultural sectors. The present conditions entail an actual hazard posed by the effects of droughts and floods. The geomorphological conditions in Poland provide an opportunity to retain up to $15 \%$ of the mean annual outflow. The sole reasonable solution is to adopt measures designed to use the natural retention capacity [8].

The scientific studies published focus mainly on the global aspects while ignoring (as reasonably emphasised in the Strategy) "regional analyses showing confirmed correlations between the causes and reasons of floods and their types and intensity, analyses of and interrelations between the structure and volumes of precipitation and its consequences in local catchment areas, separate small hydrographic systems, or local drainage areas". This study aims at supplementing necessary information about the characteristics of long-lasting precipitation series, precipitation total and mean values in areas particularly exposed to extreme events: the upper Vistula River basin and the upper and middle Oder River basin [8].

Table 1. A statement of annual balances of water resources in the upper Vistula and the upper and middle Oder for the period 1901-2010 [8].

\begin{tabular}{|c|c|c|c|c|c|}
\hline $\begin{array}{l}\text { Region of water } \\
\text { resources assessment }\end{array}$ & $\begin{array}{l}\text { Area } \\
{\left[\mathrm{km}^{2}\right]}\end{array}$ & \begin{tabular}{|c|} 
Total of precipitation p.a. \\
mean values for the long- \\
term period[mm], \\
GPCC data
\end{tabular} & $\begin{array}{l}\text { Volume } \\
\text { [billion } \mathbf{m}^{3} / \\
\text { year] }\end{array}$ & $\begin{array}{c}\text { Trend } \\
\text { [mm/year] }\end{array}$ & $\begin{array}{c}\text { Trend } \\
\text { [milion } \mathbf{~ m}^{3} / \\
\text { year] }\end{array}$ \\
\hline Poland & 312,679 & 619.1 & 193.58 & 0.002 & 0.625 \\
\hline upper Vistula & 43,109 & 742.3 & 32.00 & 0.294 & 12.674 \\
\hline $\begin{array}{c}\text { upper and middle } \\
\text { Oder }\end{array}$ & 53,467 & 671.8 & 35.92 & -0.236 & -12.618 \\
\hline
\end{tabular}




\section{The role of GPCC Precipitation Climatology Centre in collecting and providing precipitation data}

The intense interest in analyses of long-lasting precipitation series results from the need to assess climate changes and their effects on all spatial scales. This demand has led to numerous research and monitoring programmes initiated, supported and carried out by international organizations. In this context, the Global Precipitation Climatology Centre(GPCC) was established in 1989 by the World Meteorological Organization (WMO). The Centre is supported and operated by the DeutscherWetterdienst (DWD, the German Meteorological Office) as a German contribution to the World Climate Research Programme (WCRP) [9].

The main objective of the GPCC is a global analysis of monthly precipitation on Earth land surface based on data provided by "in-situ" precipitation stations. In 1994, GPCC was requested by the WMO to support climate monitoring activities carried out by the Global Climate Observing System (GCOS). The GPCC has joined the GCOS network (GSNMC) in 1999, focusing on atmospheric precipitation while temperature monitoring is conducted by the Japan Meteorological Agency (JMA) [9].

The objective of the GPCC is to meet the users' demand for accurate analyses, current and readily available datasets. All GPCC products represent gridded near and non-real-time datasets of precipitation on the Earth land surface. Only monthly data is made available in spatial resolutions $0.5^{\circ} \times 0.5^{\circ}$ to $2.5^{\circ} \times 2.5^{\circ}$ of geographic longitude and latitude. The datasets are made available on the Internet (http://gpcc.dwd.de). The products are developed based on complete sets of information from the world precipitation database originating from more than 97000 stations that provide protected and classified raw records.

\section{Characteristics of data}

The GPCC data representing total precipitation volumes in individual months in the period 1901-2010, with a spatial resolution of $0.5^{\circ} \times 0.5^{\circ}$ of geographic longitude and latitude, converted to the analysed area of Polish catchment basin. Thus a sequence of monthly precipitation values was obtained that is analysed in this study.

The calculated sequence values were subject to a simple statistical analysis in order to determine the basic statistics: the minimum and maximum values, the mean value, standard deviation of the sample and the value of the coefficient of variation.

The data is analysed using profiles modelled for individual calendar years and for hydrological years divided into hydrological summers and hydrological winters. The analyses of monthly precipitation cover the years 1901-2010, and the analyses of cumulative monthly total values of precipitation cover the hydrological years 1902-2010.

\section{An assessment of accuracy of the GPCC data for the period 1961-1990 in the territory of Poland}

An analysis of error of mean monthly values of total precipitation for 43 locations was completed to verify the data. The verification covered the period of 30 years from 1961 to 1990 (comparable data was available for that period [10]). The results of data verification demonstrate errors amounting to a few percent for 38 locations. For 5 locations: Jelenia Góra, Kętrzyn, Kłodzko, Legnica, Przemyśl, the error values exceed 10\% [8]. 


\section{Selected analyses in the territory of Poland, data for the years 1901-2010}

Table 2. A statement of monthly precipitation values and selected statistics for the period 1901-2010 in the Polish catchment basin.

\begin{tabular}{|l|c|c|c|c|c|c|c|c|c|c|c|c|}
\hline \multirow{2}{*}{ Year } & \multicolumn{7}{|c|}{ Months of the calendar year, Statistics } \\
\cline { 2 - 12 } & 'I' & 'II' & 'III' & 'IV' & 'V' & 'VI' & 'VII' & 'VIII' & 'IX' & 'X' & 'XI' & 'XII' \\
\hline Min, [mm] & 7.15 & 4.95 & 8.05 & 6.16 & 16.48 & 24.54 & 25.09 & 32.86 & 15.57 & 3.77 & 11.18 & 7.53 \\
\hline Max, [mm] & 89.65 & 67.94 & 72.48 & 74.09 & 142.84 & 128.23 & 175.25 & 159.98 & 112.92 & 162.51 & 90.12 & 79.78 \\
\hline Mean, [mm] & 36.23 & 30.74 & 34.12 & 40.93 & 59.06 & 72.01 & 84.98 & 76.95 & 52.92 & 44.66 & 45.47 & 40.97 \\
\hline $\begin{array}{l}\text { Stand, deviation of the } \\
\text { sample, S },[\mathrm{mm}]\end{array}$ & 14.20 & 11.81 & 13.69 & 12.83 & 17.91 & 20.63 & 28.55 & 22.94 & 20.13 & 24.33 & 15.58 & 15.68 \\
\hline $\begin{array}{l}\text { Coefficient of } \\
\text { variation, } \mathrm{C}_{\mathrm{V}}[-]\end{array}$ & 0.39 & 0.38 & 0.40 & 0.31 & 0.30 & 0.29 & 0.34 & 0.30 & 0.38 & 0.54 & 0.34 & 0.38 \\
\hline
\end{tabular}

Table 3. A statement of mean monthly values of total precipitation, cumulative in a hydrological year and in the summer and winter seasons with selected statistics for the period 1901-2010 in the territory of Poland.

\begin{tabular}{|c|c|c|c|c|c|c|c|c|c|c|c|c|c|c|}
\hline \multirow{2}{*}{ Year } & \multicolumn{7}{|c|}{ Months of the hydrological year, Statistics } & \multicolumn{3}{c|}{$\begin{array}{c}\text { Hydrological } \\
\text { seasons }\end{array}$} \\
\cline { 2 - 16 } & 'XI' & 'XII' & 'I' & 'II' & 'III' & 'IV' & 'V' & 'VI' & 'VII' & 'VIII' & 'IX' & 'X' & $\begin{array}{c}\text { Winter } \\
(\text { XI-IV) }\end{array}$ & $\begin{array}{c}\text { Summer } \\
\text { (V-X) }\end{array}$ \\
\hline $\begin{array}{c}\text { Min, } \\
{[\mathrm{mm}]}\end{array}$ & 11.2 & 35.8 & 54.9 & 91.6 & 109.6 & 144.2 & 202.3 & 251.5 & 324.3 & 382.0 & 420.9 & 465.2 & 144.2 & 263.0 \\
\hline $\begin{array}{c}\text { Max, } \\
{[\mathrm{mm}]}\end{array}$ & 84.4 & 148.1 & 213.3 & 251.6 & 283.3 & 330.3 & 393.1 & 491.2 & 582.6 & 678.1 & 743.8 & 762.5 & 330.3 & 571.1 \\
\hline $\begin{array}{c}\text { Mean, } \\
{[\mathrm{mm}]}\end{array}$ & 45.1 & 85.9 & 122.3 & 153.1 & 187.1 & 227.9 & 287.2 & 359.0 & 444.3 & 521.3 & 574.4 & 619.1 & 227.9 & 391.2 \\
\hline $\mathrm{S}_{\mathrm{d}}[\mathrm{mm}]$ & 15.0 & 21.3 & 27.8 & 29.4 & 35.0 & 37.5 & 41.1 & 45.6 & 53.3 & 59.6 & 65.2 & 69.7 & 37.5 & 57.6 \\
\hline $\mathrm{C}_{\mathrm{v}}[-]$ & 0.332 & 0.248 & 0.227 & 0.192 & 0.187 & 0.164 & 0.143 & 0.127 & 0.120 & 0.114 & 0.114 & 0.113 & 0.164 & 0.147 \\
\hline
\end{tabular}

\subsection{Periodicity of precipitation}

The periodicity of precipitation in the Polish catchment basin was assessed using signal processing theory with a harmonic analysis applied. The procedures necessary to calculate the values of predominating frequencies were developed in Matlab. The inverses of those values represent the predominating period of repeatability of an event. The analysis was completed for various profiles of the analysed dataset [8]. The periodicity of monthly precipitation considered using monthly profiles of calendar years in the analysed period 1901-2010 may be described as follows: February is characterised by a long predominating period of repeatability: 55 years while predominating periods of repeatability for the remaining months amount to 2.3 to 36 years. Period of repeatability of minimum values: 11 years, maximum values: 3 years, medium values: 10 years (Table 4 ). 
Table 4. A statement of periodicity values (inverses of predominating frequencies) for mean monthly precipitation sequences in the period 1901-2010 by months in the territory of Poland.

\begin{tabular}{|c|c|c|c|c|c|c|c|c|c|c|c|c|c|c|c|c|c|}
\hline \multirow{3}{*}{$\begin{array}{c}\text { Analysed } \\
\text { sequence profile }\end{array}$} & \multicolumn{12}{|c|}{ Periodicity on months of the calendar year } & \multicolumn{5}{|c|}{ Periodicity of statistics } \\
\hline & 'I' & 'II' & 'III' & 'IV' & 'V' & 'VI' & 'VII' & 'VIII' & 'IX' & 'X' & 'XI' & 'XII' & Min & $\operatorname{Max} 1$ & Mean & $\mathrm{S}_{\mathrm{d}}$ & $\mathrm{C}_{\mathrm{v}}$ \\
\hline & \multicolumn{12}{|c|}{ [years] } & \multicolumn{5}{|c|}{ [years] } \\
\hline $\begin{array}{l}\text { Predominating } \\
\text { period in years }\end{array}$ & 4.54 & 54.50 & 7.79 & 2.32 & 36.33 & 9.08 & 3.89 & 4.04 & 7.79 & 5.74 & 3.30 & 6.41 & 10.90 & 3.21 & 9.91 & 5.45 & 5.45 \\
\hline
\end{tabular}

The periodicity of total monthly precipitation calculated using hydrological year profiles in the analysed period 1902-2010 is characterised by several predominating periods of 2, 3, 5 and 10 years. In an analysis of predominating frequencies, the 3 -year periods for the months December-February, June and October are clearly identifiable. The periodicity of total monthly precipitation calculated using hydrological summer and hydrological winter profiles equals 27 years for the winter season and 36 years for the summer season. With an increasing total of precipitation in individual months of the hydrological year, a drop in periodicity is observed - from 22 years to about 2.5 years (Table 5 ).

Table 5. A statement of periodicity values (inverses of predominating frequencies) for sequences of cumulative total of mean monthly precipitation in the period 1901-2010

by hydrological years in the territory of Poland.

\begin{tabular}{|c|c|c|c|c|c|c|c|c|c|c|c|c|c|c|}
\hline \multirow{3}{*}{$\begin{array}{c}\text { Analysed } \\
\text { sequence profile }\end{array}$} & \multicolumn{12}{|c|}{ Months of the hydrological year } & \multicolumn{2}{|c|}{$\begin{array}{c}\text { Seasons of the } \\
\text { hydrological year }\end{array}$} \\
\hline & 'XI' & 'XII' & 'I' & 'II' & 'III' & 'IV' & $' V^{\prime}$ & 'VI' & 'VII' & 'VIII' & 'IX' & ' $\mathbf{X}$ & $\begin{array}{l}\text { Winter } \\
\text { (XI-IV) }\end{array}$ & $\begin{array}{l}\text { Winter } \\
(\mathbf{X I - I V})\end{array}$ \\
\hline & \multicolumn{14}{|c|}{ [years] } \\
\hline $\begin{array}{l}\text { Predominating } \\
\text { period in years }\end{array}$ & 21.60 & 3.00 & 3.00 & 3.00 & 5.40 & 27.00 & 5.40 & 2.63 & 9.82 & 9.82 & 9.82 & 2.45 & 27 & 36 \\
\hline
\end{tabular}

\subsection{Premises for an analysis of climate changes}

The image of trend in climate changes obtained using total monthly precipitation profiles for the hydrological year is described by linear equations with indicated boundary values of coefficients determined at a 5\% significance level [8]. The linear trend form is characterised mainly by a slope in $\mathrm{mm} / \mathrm{year}$. The slope value shows a positive trend for the analysed period 1902-2010: $0.002 \mathrm{~mm} /$ year at a $95 \%$ confidence level defined by the boundary values equal -0.422 to $0.427 \mathrm{~mm} /$ year.

The months of January, April, June, August, October and November are characterised by a decreasing trend in precipitation while the remaining months by a positive trend. The values vary between -0.125 in August and $+0.046 \mathrm{~mm} /$ year in March (Table 6). An analysis of trends in statistics, i.e. the identified negative trend in minimum values, the positive trend in maximum values and the positive trend in measures of variation, confirms the polarisation of meteorological phenomena and an increase in their intensity.

Table 6. Slope values of the linear trend in monthly precipitation in a calendar year in the analysed period in the territory of Poland.

\begin{tabular}{|c|c|c|c|c|c|c|c|c|c|c|c|c|c|c|c|c|}
\hline \multicolumn{12}{|c|}{ Months of the calendar year } & \multicolumn{5}{|c|}{ Trend of statistics } \\
\hline 'I' & 'II' & 'III' & 'IV' & ' $\mathbf{V}^{\prime}$ & 'VI' & 'VII' & 'VIII' & 'IX' & 'X' & 'XI' & 'XII' & Min & Max & Mean & $\mathbf{S}_{\mathrm{d}}$ & $C_{v}$ \\
\hline \multicolumn{12}{|c|}{$[\mathrm{mm} / \mathrm{month}]$} & \multicolumn{5}{|c|}{ [1/month] } \\
\hline $\begin{array}{l}1 \\
\text { : } \\
\text { N్ }\end{array}$ & $\begin{array}{l}\dot{0} \\
\dot{0}\end{array}$ & $\begin{array}{l}\stackrel{0}{0} \\
\dot{+}\end{array}$ & $\begin{array}{l}\dot{1} \\
\dot{0} \\
\text { Uू }\end{array}$ & $\begin{array}{l}0 \\
\dot{8}\end{array}$ & $\begin{array}{l}\stackrel{\circ}{\dot{\phi}} \\
\dot{\phi}\end{array}$ & $\begin{array}{l}\dot{1} \\
\dot{8}\end{array}$ & $\stackrel{\dot{0}}{\stackrel{N}{u}}$ & $\begin{array}{l}\dot{0} \\
\dot{0} \\
\text { 足 }\end{array}$ & $\begin{array}{l}1 \\
0 \\
8 \\
0\end{array}$ & $\begin{array}{l}\stackrel{0}{0} \\
\stackrel{0}{N}\end{array}$ & $\stackrel{\text { }}{\dot{8}}$ & $\begin{array}{l}\dot{1} \\
\text { ○ } \\
8\end{array}$ & $\stackrel{\circ}{\circ}$ & $\begin{array}{l}\circ \\
\dot{8}\end{array}$ & 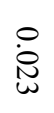 & $\begin{array}{l}\stackrel{\circ}{8} \\
\dot{8} \\
\stackrel{\mathscr{U}}{\circ}\end{array}$ \\
\hline
\end{tabular}




\section{Selected analyzes for the upper Vistula area, data in the period 1901-2010}

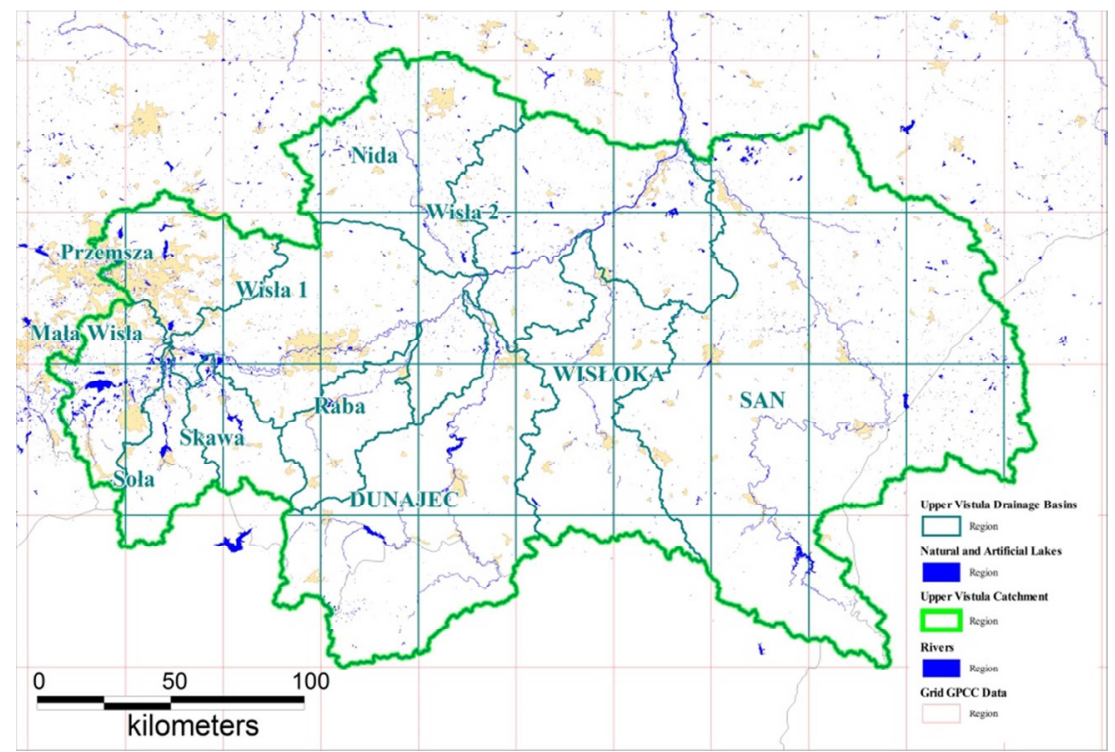

Fig. 1. Upper Vistula catchment and drainage basins on grid GPCC data.

The values of monthly precipitation for the upper Vistula river basins are calculated using GIS interpolation methods. The GPCC data representing total precipitation volumes in individual months in the period 1901-2010, with a spatial resolution of $0.5^{\circ} \times 0.5^{\circ}$ of geographic longitude and latitude, converted to the analysed area of the Vistula river basin. A sequence of monthly precipitation values was obtained and is analysed below. The calculated sequence values were subject to a simple statistical analysis in order to determine the basic statistics: the minimum and maximum values, the mean value, standard deviation of the sample and the value of the coefficient of variation. The data is analysed using profiles modelled for individual calendar years and for hydrological years divided into hydrological summers and hydrological winters. The analyses of monthly precipitation cover the years 1901-2010, and the analyses of cumulative monthly total values of precipitation cover the hydrological years 1902-2010 [8].

Table 7. A statement of selected statistics for monthly precipitation in the period 1901-2010 in the upper Vistula river basin.

\begin{tabular}{|l|c|c|c|c|c|c|c|c|c|c|c|c|}
\hline & \multicolumn{10}{|c|}{ Months of the calendar year } \\
\cline { 2 - 14 } & 'I' & 'II' & 'III' & 'IV' & ' '' & 'VI' & 'VII' & 'VIII' & 'IX' & 'X' & 'XI' & 'XII' \\
\hline Min, [mm] & 11.1 & 4.0 & 3.7 & 10.3 & 19.6 & 36.3 & 21.9 & 29.7 & 10.9 & 3.1 & 2.8 & 6.4 \\
\hline Max, [mm] & 91.2 & 83.9 & 90.2 & 116.2 & 233.0 & 179.0 & 221.2 & 200.6 & 165.7 & 171.6 & 107.5 & 85.9 \\
\hline Mean, [mm] & 39.2 & 35.5 & 39.6 & 51.1 & 78.8 & 97.2 & 105.1 & 90.8 & 63.5 & 51.3 & 48.0 & 42.1 \\
\hline $\begin{array}{l}\text { Stand. deviation of } \\
\text { the sample, } \text { S }_{\mathrm{d}} \\
\text { [mm] }\end{array}$ & 17.10 & 16.23 & 19.12 & 20.21 & 29.87 & 30.38 & 42.45 & 29.98 & 28.66 & 31.13 & 19.58 & 17.30 \\
\hline $\begin{array}{l}\text { Coefficient of } \\
\text { variation, } \mathrm{C}_{\mathrm{v}}[-]\end{array}$ & 0.44 & 0.46 & 0.48 & 0.40 & 0.38 & 0.31 & 0.40 & 0.33 & 0.45 & 0.61 & 0.41 & 0.41 \\
\hline
\end{tabular}


Table 8. A statement of statistics for total monthly precipitation, cumulative for a hydrological year and in the summer and winter seasons in the period 1901-2010 in the upper Vistula river basin.

\begin{tabular}{|c|c|c|c|c|c|c|c|c|c|c|c|c|c|c|}
\hline \multirow{2}{*}{ Year } & \multicolumn{9}{|c|}{ Months of the hydrological year, Statistics } & \multicolumn{2}{c|}{$\begin{array}{c}\text { Hydrological } \\
\text { seasons }\end{array}$} \\
\cline { 2 - 16 } & 'XI' & 'XII' & 'I' & 'II' & 'III' & 'IV' & 'V' & 'VI' & 'VII' & 'VIII' & 'IX' & 'X' & $\begin{array}{c}\text { Winter } \\
\text { (XI-IV) }\end{array}$ & $\begin{array}{c}\text { Summer } \\
\text { (V-X) }\end{array}$ \\
\hline $\begin{array}{c}\text { Min, } \\
{[\mathrm{mm}]}\end{array}$ & 2.8 & 29.5 & 50.5 & 81.6 & 109.4 & 146.7 & 206.8 & 291.0 & 316.2 & 389.7 & 450.1 & 495.3 & 146.7 & 317.1 \\
\hline $\begin{array}{c}\text { Max, } \\
{[\mathrm{mm}]}\end{array}$ & 107.5 & 163.2 & 234.1 & 276.6 & 313.2 & 400.2 & 504.4 & 633.7 & 783.4 & 911.3 & 1025.9 & 1040.4 & 400.2 & 769.0 \\
\hline $\begin{array}{c}\text { Mean, } \\
{[\mathrm{mm}]}\end{array}$ & 48.0 & 90.0 & 129.2 & 164.9 & 204.5 & 255.4 & 334.5 & 431.0 & 536.4 & 627.1 & 690.9 & 742.3 & 255.4 & 486.9 \\
\hline $\mathrm{S}_{\mathrm{d}}[\mathrm{mm}]$ & 19.6 & 25.0 & 33.4 & 36.7 & 43.8 & 49.5 & 59.4 & 69.0 & 85.0 & 93.7 & 97.9 & 100.3 & 49.77 & 84.96 \\
\hline $\mathrm{C}_{\mathrm{v}}[-]$ & 0.408 & 0.278 & 0.259 & 0.222 & 0.214 & 0.194 & 0.178 & 0.160 & 0.158 & 0.149 & 0.142 & 0.135 & 0.19 & 0.17 \\
\hline
\end{tabular}

\subsection{A taxonomic analysis of precipitation in the upper Vistula area}

A taxonomic analysis of calendar year profiles was completed using the calculated statistics for monthly precipitation: the mean value, the standard deviation of the sample and the coefficient of variation. The objective of the calculations was to determine year clusters and to identify drought and flood periods. The algorithm is graphically depicted as a dendrogram with its nodes representing clusters and its leaves representing objects. The leaves are located on the zero level, and the nodes at a height corresponding to the measure of dissimilarity between clusters represented by the descendant nodes [8].

One of the most popular cluster analyses in the hydrology, developed by Ward (1963), is used in this study. The measure is determined based on an analysis of variance. The Ward's method belongs to the family of agglomerative clustering methods. It is recognised as the most effective method in generating uniform clusters.

The results of clustering monthly precipitation in the years 1901-2010 described by mean values, standard deviations and coefficients of variation using the Ward's method are represented as a cluster tree. The analysis focuses on a detailed representation of two extreme clusters identified as drought and flood periods in the upper Vistula area (Figure 2) [8].
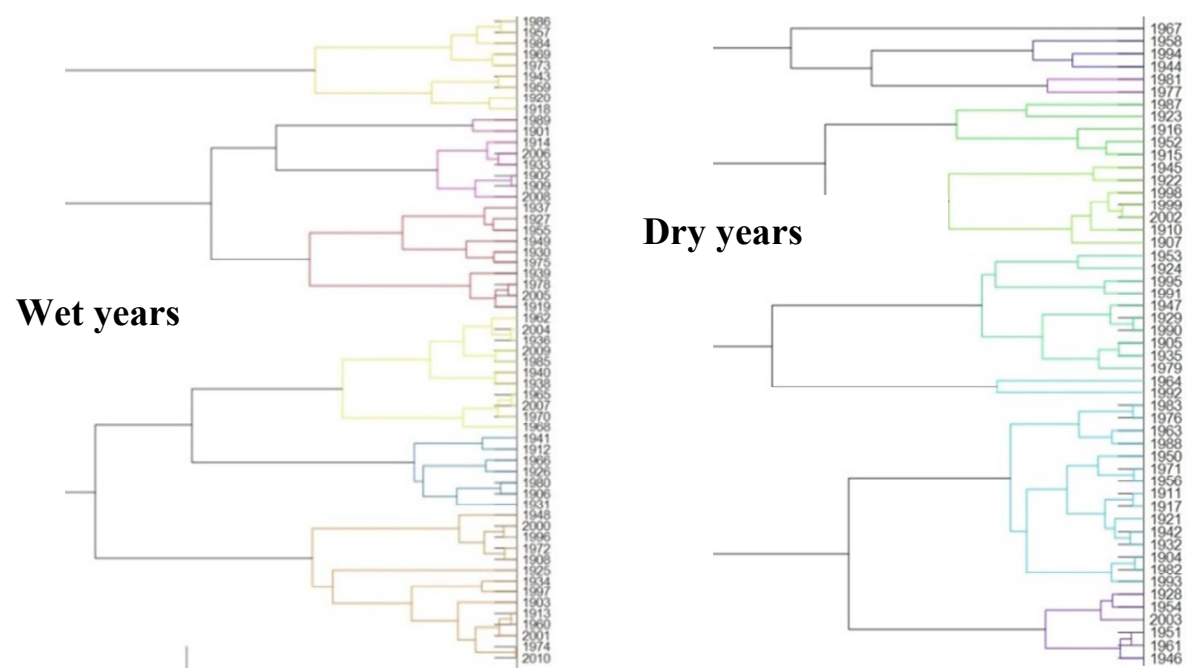

Fig. 2. The cluster of "wet years" and "dry years" classified according to mean monthly precipitation in the upper Vistula river basin. 
The cluster of "wet years" represents the levels of mean monthly precipitation in the upper Vistula drainage basin ranging from 50.69 to $86.44 \mathrm{~mm}$, standard deviation ranging from 30.14 to $64.63 \mathrm{~mm}$ and the coefficient of variation - from 0.39 to 0.89 . All calendar years with floods in the upper Vistula area are distinguished in the cluster. The years with extreme precipitation values include 2010 and (the first 10): 1974, 2001, 1960, 1913, 1903, 1997, 1934, 1925, 1908..., (Figure 2, the left-hand side). The cluster includes 59 years in total, i.e. almost $54 \%$ of the analysed period.

In contrast, the cluster of drought years includes the years when the values of mean monthly precipitation in the upper Vistula river basin ranged from 45.33 to $68.69 \mathrm{~mm}$, standard deviation ranged from 15.61 to $36.79 \mathrm{~mm}$ and the coefficient of variation - from 0.30 to 0.68 . Based on the analysed data set, the years with the most extreme droughts include: 1977, 1981, 1944, 1994, 1958, 1967..., (Figure 2, the right-hand side), This cluster includes 51 years in total, i.e. almost $46 \%$ of the analysed period.

\subsection{Periodicity of precipitation}

The periodicity of precipitation in the upper Vistula drainage basin was assessed using theory of signal processing with a harmonic analysis applied. The developed procedures were used to calculate the values of predominating frequencies. The inverses of those values represent the predominating periods of repeatability of an event. The frequency producing the maximum power of signal indicates the inverse of the predominating period [8]. The analysis was completed for various profiles of the analysed dataset. The results are shown in Tables 9, 10.

The periodicity of monthly precipitation calculated using monthly profiles of a calendar year in the analysed period 1901-2010 may be characterised as follows: September is characterised by the absence of periodicity (the periodicity almost equals the number of years described by the analysed sequence) while the predominating period of repeatability for the remaining months ranges from 2.1 to 12.11 years. Periods of repeatability: 3.6 years for minimum values, 36.3 years for maximum values, 3.5 years for medium values (Table 9).

Table 9. A statement of periodicity values for mean monthly precipitation sequences in the period 1901-2010 by months in the upper Vistula river basin.

\begin{tabular}{|c|c|c|c|c|c|c|c|c|c|c|c|c|c|c|c|c|c|}
\hline \multirow{3}{*}{$\begin{array}{c}\text { Analysed } \\
\text { sequence profile }\end{array}$} & \multicolumn{12}{|c|}{ Months of the calendar year } & \multicolumn{5}{|c|}{ Periodicity of statistics } \\
\hline & 'I' & 'II' & 'III' & 'IV' & ' $\mathbf{V}^{\prime}$ & 'VI' & 'VII' & 'VIII' & 'IX' & 'X' & 'XI' & 'XII' & Min & $\operatorname{Max}$ & Mean & $\mathrm{S}_{\mathrm{d}}$ & $\mathrm{C}_{\mathrm{v}}$ \\
\hline & \multicolumn{12}{|c|}{ [years] } & \multicolumn{5}{|c|}{ [years] } \\
\hline $\begin{array}{l}\text { Predominating } \\
\text { period in years }\end{array}$ & 4.19 & 4.04 & 7.79 & 2.32 & 2.66 & 12.11 & 3.89 & 2.10 & 109.0 & 5.74 & 3.03 & 2.87 & 3.63 & 36.33 & 3.52 & 12.11 & 5.45 \\
\hline
\end{tabular}

The periodicity of total monthly precipitation calculated using hydrological year profiles in the analysed years 1902-2010 is characterised by two periods of 3 years and 13 years. An analysis demonstrates a distinct repeatability period for October: 36 years (Table 10).

Table 10. A statement of periodicity values for sequences of cumulative total of mean monthly precipitation in the period 1901-2010 by hydrological years in the upper Vistula river basin.

\begin{tabular}{|c|c|c|c|c|c|c|c|c|c|c|c|c|}
\hline \multirow{2}{*}{$\begin{array}{c}\text { Analysed } \\
\text { sequence } \\
\text { profile }\end{array}$} & \multicolumn{10}{|c|}{ Months of the hydrological year } \\
\cline { 2 - 12 } & 'XI' & 'XII' & 'I' & 'II' & 'III' & 'IV' & 'V' & 'VI' & 'VII' & 'VIII' & 'IX' & 'X' \\
\hline $\begin{array}{l}\text { Predominating } \\
\text { period in years }\end{array}$ & 3.00 & 3.00 & 3.00 & 3.00 & 13.50 & 13.50 & 13.50 & 3.60 & 3.48 & 2.08 & 3.48 & 36.00 \\
\hline
\end{tabular}


The periodicity of total monthly precipitation calculated using hydrological summer (May-October) and hydrological winter (November-April) profiles in the analysed period 1902-2010 equals 13.5 years for the winter season and 36 years for the summer season.

\subsection{Premises for an analysis of climate changes}

The trend in climate changes identified using monthly precipitation profiles is described by linear equations with indicated boundary values of coefficients determined at a $5 \%$ significance level. The linear trend form is characterised mainly by a slope in mm/year [8].

In the analysed trend resulting from total monthly precipitation profiles in a hydrological year over the analysed period 1902-2010 (109 years), the value of slope is positive and equals $0.294 \mathrm{~mm} /$ year. The lower and upper limits of ranges for a $95 \%$ confidence interval are: $-0.314 \mathrm{~mm} /$ year and $0.903 \mathrm{~mm} /$ year.

Similarly, the trend in climate changes reflecting monthly precipitation profiles in a calendar year adopts negative and positive values. The months of January, August and October are characterised by a decreasing trend in precipitation while the remaining months by a positive trend. The values vary between -0.113 in August and $+0.139 \mathrm{~mm} / \mathrm{month}$ in May (Table 11).

Table 11. Values of parameters of the linear trend in monthly precipitation in a calendar year in the analysed period in the upper Vistula river basin.

\begin{tabular}{|c|c|c|c|c|c|c|c|c|c|c|c|c|c|c|c|c|c|}
\hline & \multicolumn{12}{|c|}{ Months of the hydrological year } & \multicolumn{5}{|c|}{ Trend of statistics } \\
\hline & 'I' & 'II' & 'III' & 'IV' & ' ${ }^{\prime}$ & 'VI' & 'VII' & 'VIII' & 'IX' & ' $\mathbf{X}$ & 'XI' & 'XII' & $\min$ & $\max$ & Mean & Sd & $\mathrm{Cv}$ \\
\hline & \multicolumn{12}{|c|}{ [mm/month] } & \multicolumn{5}{|c|}{$[-]$} \\
\hline $\begin{array}{l}\text { Slope } \\
\text { value }\end{array}$ & 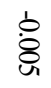 & ஜ̊ & ஜ̊ & 尽 & : & $\stackrel{8}{8}$ & : & $\stackrel{b}{\dot{\omega}}$ & 8 & $\begin{array}{l}\dot{1} \\
\text { \&̊ }\end{array}$ & 8 & 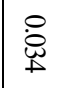 & \&̊ & 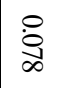 & : & \& & 8 \\
\hline $\begin{array}{c}\text { Lower limit } \\
\text { at a } 95 \% \\
\text { confidence } \\
\text { level }\end{array}$ & b & 容 & 客 & 官 & 它 & 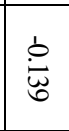 & 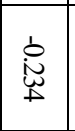 & 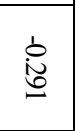 & 葟 & $\begin{array}{l}\dot{0} \\
\text { N్} \\
\text { o }\end{array}$ & $\stackrel{b}{\omega}$ & 这 & 官 & 寀 & 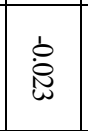 & 宓 & 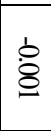 \\
\hline $\begin{array}{c}\text { Upper limit } \\
\text { at a } 95 \% \\
\text { confidence } \\
\text { level }\end{array}$ & : & 它 & $\stackrel{\infty}{\infty}$ & $\stackrel{\circ}{\stackrel{D}{\infty}}$ & $\stackrel{i}{a}$ & $\underset{\sim}{\stackrel{\sim}{N}}$ & 엉 & : & $\begin{array}{l}\text { ్ㅗ } \\
\text { S }\end{array}$ & 邁 & $\stackrel{\circ}{N}$ & 它 & : & 엉 & 음 & : & 8 \\
\hline
\end{tabular}

\section{Upper Vistula drainage basins}

A detailed analysis of mean precipitation in the upper Vistula area over the long period was completed for the following drainage basins (Figure 1): the Little Vistula, the Vistula 1 including the direct drainage basin of the Vistula from the Little Vistula to the confluence with the Nida, the Przemsza, the Sola, the Skawa, the Raba, the Dunajec, the Vistula 2 including the direct drainage basin of the Vistula from the Nida to the confluence with San and the Wisłoka. The analysed drainage basins are also identified in the Map of Hydrographic Divides in Poland developed by the Institute of Meteorology and Water Management, recommended for and used in analyses performed as part of broadly understood water management.

The trends in precipitation in the water balance basins of the upper Vistula significantly vary (Table 12) and adopt the values from $0.689 \mathrm{~mm} /$ year in the San drainage basin to -0.427 in the Nida drainage basin. Such a significant disparity indicates the urgent need for scenarios designed to compensate changes in water resource volumes. 
Table 12. A statement of annual balances of water resources in upper Vistula drainage basins.

\begin{tabular}{|c|c|c|c|c|c|c|}
\hline $\begin{array}{c}\text { Region of water } \\
\text { resources } \\
\text { assessment }\end{array}$ & $\begin{array}{c}\text { Kod ID_HYD } \\
\text { according to } \\
\text { MPHP database } \\
\text { system }\end{array}$ & $\begin{array}{c}\text { Area } \\
{\left[\mathbf{k m}^{2}\right]}\end{array}$ & $\begin{array}{c}\text { Total of precipitation p.a. } \\
\text { mean values for the long- } \\
\text { term period [mm], } \\
\text { GPCC data }\end{array}$ & $\begin{array}{c}\text { Volume } \\
\mathbf{V} \\
\text { [billion } \\
\left.\mathbf{m}^{3} / \mathbf{y e a r}\right]\end{array}$ & $\begin{array}{c}\text { Trend } \\
{[\mathbf{m m} / \mathbf{y e a r}]}\end{array}$ & $\begin{array}{c}\text { Trend } \\
\text { [million } \\
\left.\mathbf{m}^{3} / \mathbf{y e a r}\right]\end{array}$ \\
\hline San & 22 & $16,803.31$ & 708.64 & 11.91 & 0.689 & 11.572 \\
\hline Przemsza & 212 & $2,118.73$ & 724.22 & 1.53 & -0.172 & -0.364 \\
\hline Dunajec & 214 & $6,776.59$ & 873.26 & 5.92 & 0.532 & 3.603 \\
\hline Nida & 216 & $3,832.13$ & 628.09 & 2.41 & -0.427 & -1.635 \\
\hline Wisloka & 218 & 4085.7 & 731.39 & 2.99 & 0.520 & 2.126 \\
\hline Mala Wisla & 2110 & $1,816.09$ & 878.56 & 1.60 & 0.242 & 0.440 \\
\hline Wisla 1 & 2111 & $5,068.79$ & 711.88 & 3.61 & -0.200 & -1.012 \\
\hline Wisla 2 & 2112 & $5,541.53$ & 618.79 & 3.43 & 0.031 & 0.171 \\
\hline Sola & 2132 & 1357.4 & 957.80 & 1.30 & 0.022 & 0.030 \\
\hline Skawa & 2134 & $1,174.56$ & 898.27 & 1.06 & -0.005 & -0.006 \\
\hline Raba & 2138 & $1,532.95$ & 873.19 & 1.34 & 0.076 & 0.116 \\
\hline
\end{tabular}

Table 13. A statement of periodicity values (inverses of predominating frequencies) for mean monthly precipitation sequences in the period 1901-2010 by months in upper Vistula drainage basins.

\begin{tabular}{|c|c|c|c|c|c|c|c|c|c|c|c|c|c|c|c|c|c|}
\hline \multirow{3}{*}{$\begin{array}{c}\text { Analysed } \\
\text { sequence } \\
\text { profile }\end{array}$} & \multicolumn{12}{|c|}{ Months of the calendar year } & \multicolumn{5}{|c|}{ Periodicity of statistics } \\
\hline & ' $\mathbf{I}$ & 'II' & 'III' & 'IV' & ' $\mathbf{V}^{\prime}$ & 'VI' & 'VII' & 'VIII & 'IX' & 'X' & 'XI' & 'XII' & Min & Max & Mean & $\mathrm{S}_{\mathrm{d}}$ & $\mathrm{C}_{\mathrm{v}}$ \\
\hline & \multicolumn{17}{|c|}{ [years] } \\
\hline San & 2.60 & 3.63 & 3.52 & 27.25 & 2.66 & 6.41 & 3.89 & 2.42 & 109.0 & 5.74 & 3.03 & 109.0 & 13.63 & 4.36 & 3.52 & 3.89 & 3.89 \\
\hline Przemsza & 27.25 & 4.04 & 2.10 & 4.95 & 3.89 & 3.30 & 5.19 & 2.48 & 21.80 & 5.74 & 3.30 & 6.41 & 2.48 & 12.11 & 12.11 & 12.11 & 3.11 \\
\hline Dunajec & 27.25 & 3.76 & 7.79 & 27.25 & 12.11 & 12.11 & 5.19 & 4.54 & 109.0 & 5.74 & 3.03 & 2.87 & 2.87 & 36.33 & 36.33 & 12.11 & 5.45 \\
\hline Nida & 27.25 & 4.04 & 2.10 & 12.11 & 13.63 & 3.30 & 3.30 & 2.48 & 21.80 & 5.74 & 3.30 & 6.41 & 13.63 & 3.11 & 54.50 & 109.0 & 13.63 \\
\hline Wisłoka & 4.19 & 4.04 & 7.79 & 27.25 & 12.11 & 12.11 & 3.89 & 13.63 & $\begin{array}{ll}3.22 \\
3\end{array}$ & 5.74 & 3.03 & 54.50 & 27.25 & 4.36 & 3.52 & 36.33 & 5.45 \\
\hline $\begin{array}{l}\text { Mała } \\
\text { Wisła }\end{array}$ & 27.25 & 4.04 & 2.10 & 5.74 & 12.11 & 18.17 & 3.89 & 2.48 & 21.80 & 5.74 & 4.74 & 109.0 & 109.0 & 12.11 & 12.11 & 12.11 & 12.11 \\
\hline Wisła 1 & 27.25 & 4.04 & 2.10 & 3.52 & 4.74 & 3.30 & 13.63 & 32.48 & 21.80 & 5.74 & 3.30 & 6.41 & 4.36 & 12.11 & 12.11 & 12.11 & 109.0 \\
\hline Wisła 2 & 4.19 & 4.04 & 7.79 & 3.11 & 13.63 & 9.08 & 3.30 & 2.48 & 21.80 & 5.74 & 3.30 & 54.50 & 27.25 & 4.36 & 3.52 & 12.11 & 5.45 \\
\hline Sola & 27.25 & 4.04 & 2.10 & 5.74 & 12.11 & 12.11 & 5.19 & 4.95 & 2.79 & 5.74 & 8.38 & 4.95 & 109.0 & 12.11 & 36.33 & 12.11 & 5.74 \\
\hline Skawa & 27.25 & 4.04 & 2.10 & 2.32 & 12.11 & 12.11 & 5.19 & 4.95 & 2.95 & 5.74 & 3.03 & 4.95 & 4.36 & 12.11 & 12.11 & 12.11 & 5.74 \\
\hline Raba & 27.25 & 5.19 & 7.79 & 27.25 & 12.11 & 12.11 & 5.19 & 4.54 & 2.95 & 5.74 & 3.03 & 2.95 & 2.87 & 12.11 & 12.11 & 12.11 & 5.45 \\
\hline
\end{tabular}


Table 14. Slope values of the linear trend in monthly precipitation in a calendar year in the analysed period in upper Vistula drainage basins.

\begin{tabular}{|c|c|c|c|c|c|c|c|c|c|c|c|c|c|c|c|c|c|}
\hline & \multicolumn{12}{|c|}{ Months of the calendar year } & \multicolumn{5}{|c|}{ Trend of statistics } \\
\hline & 'I' & 'II' & 'III' & 'IV' & ' $\mathbf{C}^{\prime}$ & 'VI' & 'VII' & 'VIII' & 'IX' & 'X' & 'XI' & 'XII' & $\min$ & $\max$ & Mean & Sd & $\mathrm{Cv}$ \\
\hline & \multicolumn{12}{|c|}{$[\mathrm{mm} / \mathrm{month}]$} & \multicolumn{5}{|c|}{$[1 /$ month $]$} \\
\hline San & 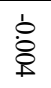 & :̊․ㅇ & 总 & 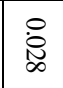 & 岕 & $\dot{0}$ & $\stackrel{\circ}{\circ}$ & bे & 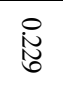 & $\stackrel{\dot{0}}{\omega}$ & ஓి & : & : & : & : & ஓి & 8े \\
\hline Przemsza & 㴔 & 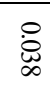 & ஜ & $\stackrel{\circ}{\stackrel{0}{N}}$ & ஜ̊ & 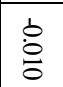 & $\underset{⿱ 亠}{0}$ & b & ஜ & : & $\stackrel{\circ}{\stackrel{0}{N}}$ & 竞 & : & 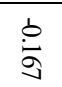 & $\stackrel{\dot{O}}{\stackrel{0}{N}}$ & 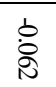 & 逭 \\
\hline Dunajec & ষి & $\stackrel{\circ}{\mathcal{W}_{u}}$ & 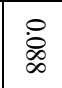 & $\stackrel{8}{\dot{1}}$ & $\stackrel{\circ}{\circ}$ & $\stackrel{0}{b}$ & $\stackrel{\circ}{\circ}$ & 菑 & $\stackrel{\circ}{0}$ & : & : & $\stackrel{\ominus}{\varrho}$ & 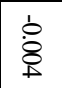 & $\begin{array}{l}\text { 证 } \\
\text { ু }\end{array}$ & 总 & 灾 & \& \\
\hline Nida & ؛े & ஜ̊ & $\stackrel{8}{\dot{\$}}$ & $\stackrel{\ominus}{\infty}$ & 兽 & !े & $\stackrel{b}{\stackrel{b}{\prime \prime}}$ & b্] & 灾 & $\stackrel{\dot{\infty}}{\infty}$ & 宓 & 㝒 & 菑 & $\stackrel{b}{\infty}$ & 总 & 交 & $\dot{\circ}$ \\
\hline Wisloka & 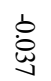 & : & ஓ̊ & 离 & $\stackrel{\circ}{\stackrel{U}{u}}$ & : & : & $\begin{array}{l}\dot{0} \\
\dot{0} \\
0\end{array}$ & : & 高 & $\stackrel{\circ}{\infty}$ & $\stackrel{\circ}{\mathscr{O}}$ & $\stackrel{\circ}{3}$ & 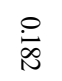 & $\stackrel{8}{8}$ & 菑 & 8े \\
\hline $\begin{array}{l}\text { Mała } \\
\text { Wisla }\end{array}$ & 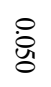 & 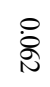 & $\stackrel{\circ}{\stackrel{\sim}{u}}$ & 它 & 응 & $\stackrel{8}{\stackrel{\leftrightarrow}{0}}$ & $\stackrel{\dot{O}}{\stackrel{0}{N}}$ & 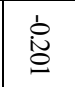 & : & : & 总 & $\stackrel{0}{8}$ & : & $\stackrel{0}{\circ}$ & : & $\stackrel{\circ}{\circ}$ & \&े \\
\hline Wisla 1 & $\stackrel{8}{\stackrel{0}{0}}$ & $\begin{array}{l}\text { : } \\
\text { ్ㅇ }\end{array}$ & : & 怘 & 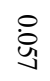 & 芯 & $\stackrel{b}{6}$ & $\begin{array}{l}\dot{0} \\
\text { 음 }\end{array}$ & 这 & 窤 & $\stackrel{b}{\stackrel{b}{0}}$ & 高 & $\stackrel{8}{\stackrel{\leftrightarrow}{0}}$ & $\stackrel{b}{\breve{t}}$ & 官 & 离 & \& \\
\hline Wisla 2 & 宫 & ஓి & 宓 & 灾 & : & 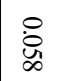 & !े & $\stackrel{\dot{D}}{\underline{N}}$ & 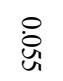 & 客 & 高 & \& & 宓 & \&̊ & 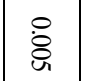 & $\underset{\infty}{\stackrel{0}{\infty}}$ & 8 \\
\hline Sola & $\stackrel{\circ}{\dot{0}}$ & $\stackrel{8}{\stackrel{8}{1}}$ & 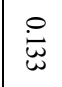 & 宫 & : & : & 㻤 & i & : & 产 & \&: & 总 & $\stackrel{8}{8}$ & 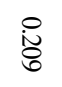 & \&̊ & $\stackrel{\circ}{\stackrel{1}{+}}$ & 8े \\
\hline Skawa & 8̊ & 巳̊ & 竞 & $\stackrel{\ominus}{\ominus}$ & $\dot{8}$ & $\begin{array}{l}\text { Oें } \\
\text { ¿ू. }\end{array}$ & : & $\begin{array}{l}\dot{0} \\
\text { 衣 }\end{array}$ & 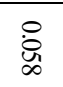 & !் & \&̊े & $\stackrel{\circ}{\circ}$ & 客 & 吾 & \&े & \&̊ & ஜे \\
\hline Raba & $\stackrel{\circ}{\circ}$ & ஜ̊ & $\stackrel{\circ}{\stackrel{0}{N}}$ & 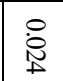 & $\stackrel{\circ}{\circ}$ & ஜ̊ & 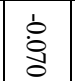 & $\begin{array}{l}\dot{U} \\
\text { 응 }\end{array}$ & ஜ & 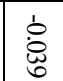 & \&్ర & 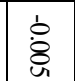 & $\stackrel{\circ}{\varrho}$ & $\stackrel{\circ}{\stackrel{్}{\prime \prime}}$ & \&̊ & $\stackrel{\circ}{\infty}$ & 8 \\
\hline
\end{tabular}

\section{Conclusions}

The study provides an opinion that is expressed considering the need for regional analyses identifying the causes of floods and droughts. The study also confirms the need for adapting policies to the ongoing climate changes, by performing regional and local analyses of those changes, as necessary to develop scenarios aimed to compensate their effects.

The identified year clusters, both the group of drought years and the group of wet years, are consistent with the extreme phenomena of droughts and floods observed over the last century.

The values of periodicity of monthly precipitation in the upper Vistula drainage basins, by months of a calendar year in the analysed period 1901-2010, may be characterised as follows: September is characterised by the absence of periodicity while the predominating period of repeatability for the remaining months ranges from 2.1 to 12.1 years. The repeatability periods of statistics: 3.6 years for the minimum value, 36.3 years for the maximum value, 3.5 years for the medium value. The repeatability of total monthly precipitation calculated using hydrological year profiles in the analysed years $1902-2010$ is characterised by two periods of 3 years and 13 years. The analysis demonstrates a distinct repeatability period for October, equal 36 years. The predominating 
repeatability of total monthly precipitation calculated using hydrological summer and hydrological winter profiles equals 13.5 years for the winter season and 36 years for the summer season.

The analyses also included an assessment of the trend in climate changes. The trend resulting from total monthly precipitation profiles for hydrological summer is described by linear equations with indicated boundary values of coefficients determined at a $5 \%$ significance level. The total of precipitation is characterised by a positive trend of $0.294 \mathrm{~mm} /$ year in the analysed period of 109 years. Similar analysis was performed for the months of calendar summer. The slope values are both negative and positive for the analysed period 1901-2010. The months of January, August and October are characterised by a decreasing trend in precipitation while the remaining months by a positive trend.

The analysis of trends in precipitation performed for water-balance areas in the upper Vistula drainage basins indicates a serious danger of an increase in precipitation phenomena in the San drainage basin $(0.689 \mathrm{~mm} / \mathrm{year})$, the Dunajec drainage basin $(0.532 \mathrm{~mm} /$ year $)$ and the Wisłoka drainage basin $(0.52 \mathrm{~mm} /$ year $)$ which should be considered in the nearest future in studies aimed to compensate anthropogenic impact on climate changes, and included in policies aimed to prevent floods (the impact should be analysed when designing the parameters of retention reservoirs and the rules for their control). The analyses of trends performed for the Nida drainage basin $(-0.427 \mathrm{~mm} / \mathrm{year})$, the Vistula 1 drainage basin $(-0.2 \mathrm{~mm} /$ year $)$ and the Skawa drainage basin $(-0.005 \mathrm{~mm} /$ year) indicate a downward trend in precipitation water resources that will result in a reduction in surface water volumes; this indicates the need for additional, diversified methods of retention. This study represents the first part of analyses performed for multiannual sequences of precipitation, and the second part discusses the results obtained for the upper and middle Oder drainage basins.

\section{References}

1. K. Kożuchowski, Wydawnictwo Biblioteka Łódź, 47-58 (2004)

2. T. Niedźwiedź, R. Twardosz, A. Walanus, Theor. Appl. Climatol., 98, 3-4, 337-350 (2009)

3. J. Degirmendžić, K. Kożuchowski, E. Żmudzka, Int. J. Climatol., 24, 3, 291-310 (2004)

4. T. Zawora, A. Ziernicka, Acta Universitatis Wratislaviensis, Studia Geograficzne, 75, 2542, 123-128 (2003)

5. A. Ziernicka-Wojtaszek, Z. Olecki. Kraków. Instytut Geografii i Gospodarki Przestrzennej UJ, 139-148 (2006)

6. E. Żmudzka, Wiadomości Instytutu Meteorologii i Gospodarki Wodnej, 25 (46), 4, 23-38 (2002)

7. M. Cebulska, R. Szczepanek, R. Twardosz, WIS PK, IGGP UJ, Kraków (2013)

8. B. Twaróg B., IOSR-JESTFT, 10, 10, 50-64 (2016)

9. R.F. Adler, G.J. Huffman, A. Chang, R. Ferraro, P. Xie, J. Janowiak, B. Rudolf, U. Schneider, S. Curtis, D. Bolvin, A. Gruber, J. Susskind, P. Arkin and E. Nelkin, Journal Hydrometeorom., 4, 1147-1167 (2003)

10. U. Kossowska-Cezak, Wydawnictwo Naukowe PWN (2000) 